\title{
Cracks in Euroland and No Way Out
}

T he European Monetary Union (EMU) has been under increased international and internal scrutiny recently. Since the outbreak of the global financial crisis long-term interest rates between member states have been driven further apart than ever before. Spain, for example, has a ten-year government bond yield which is more than one percentage point or 100 basis points higher than Germany's. For Greece the difference amounts to more than 250 basis points.

More and more observers are asking questions about the long-run viability of a monetary system with absolutely fixed nominal exchange rates between its member states but dramatically divergent real exchange rates, current account balances and market shares inside its domestic market. Since the start of the EMU in 1999 Germany, the biggest country and the European stronghold of external stability for several decades, has de-coupled from many other member countries by keeping nominal and real wage growth far below the pace given by the inflation rate target of the European central bank (ECB).

Nominal unit labour costs are the surrogate of the real exchange rate in systems of absolutely fixed nominal exchange rates. The real exchange rate approximates the purchasing power of a nation's currency in comparison to its trading partners: if it is high, buying abroad is cheap and, correspondingly, if it is low, buying abroad is expensive. Rising divergences between Germany's unit labour costs and those of the other EMU member states point to an unsustainable real depreciation of the German relative cost position in a system that has abandoned the use of nominal exchange rates as an instrument to compensate for such divergences.

For a long time the visible deterioration of competitiveness in Italy, Spain and Portugal was defended by the fact that Germany has a long-standing tradition, reaching back to the 1950s, of undervaluation and of running huge trade surpluses. In this view, it is obvious that the tremendous shock of German unification only interrupted Germany's tradition of running high current account surpluses and that Germany today is in the process of reestablishing this kind of "normality". In the second half of the 1990s, impressed by the real appreciation of the D-Mark and the implied loss of competitiveness as well as the weak economic performance, policymakers in Germany put enormous pressure on trade unions to forge a new consensus to regain international competitiveness. Following a tripartite agreement in 1996, the rate of nominal wage growth dropped lastingly below the sum of productivity growth and the inflation target rate as set by the Bundesbank and later by the ECB; consequently unit labour cost growth dropped far below the two per cent inflation target.

Obviously, a strategy of raising international competitiveness by setting limits for the increase of unit labour costs to rates lower than in partner countries can only be successful if the domestic currency appreciates less than needed to compensate for the "wage moderation". In the case of Germany, the de facto fixing of nominal exchange rates in the run-up to the EMU and the definite fixing of intra-regional exchange rates at the beginning of 1999 made this kind of beggar-thy-neighbour strategy possible. As a result, Germany's current account balance has improved from a deficit of 1.7 per cent of GDP in 2000 to a surplus of more than 7 per cent of GDP in 2007 - while its closest trading partners suffered corresponding movements into deficit and huge losses in market shares inside Europe and globally.

With the results of improved German competitiveness clearly identifiable in trade flows and market shares, the main argument brought forward time and again to defend the German strategy simply stated that Germany had entered the EMU at a grossly overvalued exchange rate. This argument is wrong. Germany had been the stability anchor for many European countries. The convergence of inflation rates from higher values towards the 
lower German rate implied an undervaluation of the anchor currency rather than an overvaluation. Germany's current account was balanced at the time the EMU started and its trade performance was absolutely normal. The fact that the improvement of price competitiveness immediately turned market shares, the trade balance and the current account to Germany's advantage clearly verifies the absence of a prior overvaluation. Consistently, the target of EMU was to create a level playing field for all companies in all member countries but not a jump for countries to devalue without an exchange rate.

By implication, there has been no justification for a strategy of real depreciation of the former anchor country after fixing nominal exchange rates once and for all. With its politically orchestrated wage restraint since the mid 1990s Germany has not only violated its own historical rule of keeping unit labour cost growth in line with its monetary authorities' inflation target. Germany has also fundamentally undermined the very existence of the EMU - and this despite its own experience with a miserably failed monetary union (also mainly due to wage divergences) inside Germany only a few years earlier.

To justify Germany's behaviour as a warranted restoration of previously lost competitiveness is not only to ignore the mounting intra-euro area imbalances but it is inviting partner countries which have found themselves on the other side of drastic changes in intra-euro area competitiveness positions to follow Germany's example. There is a clear risk of pushing Euroland onto a deflationary path if the deficit countries adjust their wage trends downwards by means of political pressure on wage growth or any other measure to reduce labour costs for employers. In this case the existing deflationary tendencies would quickly turn into outright deflation. It is shocking and proof of the asymmetric approach of monetary policy that the ECB as well as the Bundesbank have frequently and until today recommended exactly the German strategy to the indebted euro countries. In its monthly bulletin of September 2008 the ECB writes, "Measures that ... promote moderate unit labour cost growth are of the utmost importance in the current economic circumstances.... this is ... particularly pressing in those (euro area countries) that have experienced significant loss of cost and price competitiveness over recent years." (p.7) And the Bundesbank says in its monthly report in December 2008, "... under the rules of the game in monetary union, there are no ... economic policy alternatives to the path embarked upon here in Germany. ... Germany's experience is suited to serve as a model for other euro-area countries confronted by the problem of diminishing price competitiveness." (p.43)

The irony is that Germany had not really gained from its smart form of protectionism, its beggar-thy-neighbour policy, even before the financial crisis began. In large economies, domestic demand is more important than exports. Private consumption has stayed flat in Germany due to the fact that, since the mid 1990s, real wages have not risen while employment growth has not made up for the loss in real income per worker, thereby disproving the predictions of orthodox employment theory. Suffice it to say that more countries following Germany's example would mean magnifying the domestic demand problems in the biggest economic crisis of the last 80 years.

The EMU, as any zone of absolute stability of exchange rates, can only function if nominal wage increases in all member countries stay strictly in line with the inflation target set by the monetary authorities. Given the close correlation of unit labour cost growth and inflation, the implicit rule of the monetary union is that national nominal wage growth should be in line with the sum of national productivity progress and the European inflation target. The violation of this rule since the beginning of the currency union in 1999 has dramatically darkened the future for a historically unique experiment.

Heiner Flassbeck Director, Division on Globalisation and Development Strategies, UNCTAD, Geneva Friederike Spiecker Economist and freelance writer, Schwäbisch Gmünd 